\title{
Short Communication: Note on the genus Dorstenia Plum. ex L. (Moraceae) in Java (Indonesia) and noteworthy information on the identity of $\boldsymbol{D}$. bahiensis through ITS sequence
}

\author{
ARIFIN SURYA DWIPA IRSYAM ${ }^{1, \bullet}$, MUHAMMAD RIFQI HARIRI ${ }^{2}$, PENI WIDIYANTI ${ }^{2,3}$, \\ RINA RATNASIH IRWANTO ${ }^{4}$
}

${ }^{1}$ Herbarium Bandungense (FIPIA), School of Life Sciences and Technology, Institut Teknologi Bandung. Labtek VC Building, Jl. Letjen Purn. Dr. (HC) Mashudi No. 1, Jatinangor, Sumedang 45363, West Java, Indonesia, Tel.: +62-22-7798600. vemail: arifin@ sith.itb.ac.id, muhammad.rifqi.hariri@lipi.go.id

${ }^{2}$ Research Center for Plant Conservation and Botanic Gardens, Indonesian Institute of Sciences. J1. Ir. H. Juanda No. 13, Bogor 16022, West Java, Indonesia

${ }^{3}$ Department of Biology, Faculty of Mathematics and Natural Sciences, Institut Pertanian Bogor. Jl. Agatis, Kampus IPB Darmaga, Bogor 16680, West Java, Indonesia

${ }^{4}$ School of Life Sciences and Technology, Institut Teknologi Bandung. Labtek XI Building, Jl. Ganesha No. 10, Bandung 40132, West Java, Indonesia

Manuscript received: 20 January 2021. Revision accepted: 22 July 2021.

\begin{abstract}
Irsyam ASD, Hariri MR, Widiyanti P, Irwanto RR. 2021. Short Communication: Note on the genus Dorstenia Plum. ex L. (Moraceae) in Java (Indonesia) and noteworthy information on the identity of $\mathrm{D}$. bahiensis through ITS sequence. Biodiversitas 22: 3358-3363. Dorstenia Plum. ex L. grouped within tribe Dorstenieae in the Moraceae. The genus comprises 105 species that are distributed in the African, Asian, and Neotropical regions. Previous studies showed that Java Island has only one species of Dorstenia, namely $D$. contrajerva L. This exotic species was introduced a long time ago and naturalized in Java. The field survey was carried out in Banten, Jakarta, West Java, and East Java. Herbarium study was also carried out in Herbarium Bogoriense and Herbarium Bandungense. There are two additional species from Java, D. bahiensis Klotzsch ex Fisch. and C.A. Mey. and D. foetida (Forssk.) Schweinf. Dorstenia bahiensis originated from Eastern Brazil and was found naturalized in Mekarwangi Village, Lembang, Bandung Barat regency, Indonesia. Dorstenia foetida is native to Africa and is only found as a popular cultivated plant. A molecular approach was carried out to provide the right identity of $D$. bahiensis because it has been mistakenly labeled as D. elata by a Javanese horticulturist. The internal transcribed spacer (ITS) sequence separated and distinguished both D. bahiensis and D. elata into different clades, which makes the popular name for D. elata actually D. bahiensis. Based on this study, there are three species of exotic Dorstenia in Java. The descriptions, photographs, and further discussions are provided.
\end{abstract}

Keywords: Alien, Dorstenia, Java, Moraceae, tusuk konde

\section{INTRODUCTION}

Dorstenia Plum. ex L. is the second largest genus in the Moraceae after Ficus L. It consists of 105 species that are distributed in Africa, Asia (Arabia, Sri Lanka, and India), and Neotropics (Friis 1983; Berg et al. 2006; Misiewicz and Zerega 2012; Chase et al. 2013; de Oliveira Boeni and Singer 2015). Morphologically, Dorstenia has unique characteristics, and it can be easily distinguished from the other genera within Moraceae. This genus includes herbs, shrubs, and succulent species, whereas the woody species are only found in Africa (Berg 2001). The inflorescences of Dorstenia are bisexual, borne solitary from the axil of leaves, and vary in shape (discoid, turbinate, orbicular, elliptic, quadrangular, stellate, or lingulate). The receptacle is centrally or eccentrically attached to the peduncle, and it has an entire dentate, crenate, appendiculate, or lobed margin (Berg 2001; Berg et al. 2006). Based on its inflorescence characteristics, the genus is presumed to be the intermediate form between an open inflorescence in Morus and the specialized syconium of Ficus (Misiewicz and Zerega 2012).

Berg et al. (2006) and Backer and Bahkuizen van den Brink (1965) only recognized one species of Dorstenia in Java, namely $D$. contrajerva $\mathrm{L}$. The species is native to Mexico and Tropical America. It was introduced to Java years ago and became a naturalized alien species on the island (Berg et al. 2006). Based on our recent botanical survey and specimen observation, there are two additional species of exotic Dorstenia on Java Island, D. bahiensis Klotzsch ex Fisch. and C.A. Mey. and D. foetida (Forssk.) Schweinf. Both species are commonly known as tusuk konde plants by Javanese people. The presence of both species on the island is reported here.

\section{MATERIALS AND METHODS}

\section{Botanical exploration and specimen observation}

The field survey was conducted in Jakarta, Banten (Tangerang), West Java (Bandung, Bogor, and Sumedang), and East Java (Surabaya, Madura) from August 2019 to 
March 2020. The field exploration followed Rugayah et al. (2004). The materials from the field were collected following van Balgooy (1987). The data recorded includes collector name, collection number, locality, habitat, date, vernacular name, and morphological characteristics (i.e., the color of exudates, stem, leaves, inflorescences, and infructescences). The materials were observed at Herbarium Bandungense (FIPIA), School of Life Sciences and Technology (SITH), Institut Teknologi Bandung, and Bogor Botanic Gardens (BBG). Specimen examination was also carried out at Herbarium Bogoriense (BO), Indonesian Institute of Sciences (LIPI), Cibinong, Bogor. As many as seven sheets of herbarium specimens were observed for this study.

\section{DNA extraction, amplification, and sequencing}

Molecular analysis was carried out to confirm the identity of $D$. bahiensis as well as to compare it to the sequences of $D$. elata using the internal transcribed spacer (ITS) sequence following Sun et al. (1994). The DNA extraction and PCR process were conducted at Treub Laboratory, Bogot Botanic Gardens. The DNA was extracted using Tiangen Plant Genomic DNA Kit (Tiangen Biotech Co., Ltd.), following the manufacturer's protocol. The polymerase chain reaction was carried out in a total volume of $50 \mu \mathrm{l}$, consisting of a $5 \mu \mathrm{L}$ DNA sample, $1.5 \mu \mathrm{L}$ each of ITS forward (5'-ACGAATCATGGTCCGGTG AAGTGTTCG-3') and reverse (5'-TAGAATTCCCC GGTTCGCTCGCCGTTAC-3') primer, $25 \mu \mathrm{L}$ MyTaq

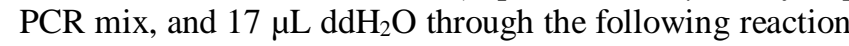
$\left[95^{\circ} \mathrm{C} 3 \mathrm{~min},\left(95^{\circ} \mathrm{C}, 30 \mathrm{~s}, 58^{\circ} \mathrm{C}\right.\right.$ for $45 \mathrm{~s}, 72^{\circ} \mathrm{C}$ for $\left.45 \mathrm{~s}\right) \times 35$ cycles], $72^{\circ} \mathrm{C}$ for $5 \mathrm{~min}$. The PCR products were sent to be sequenced at $1^{\text {st }}$ Base, Singapore.

\section{Sequence editing, alignment, and phylogenetic tree reconstruction}

The contig sequence was aligned to their homologous sequences and analyzed using MEGA X software using the Kimura 2-parameter model (Kimura 1980; Kumar et al. 2018). The reconstruction of a phylogenetic tree was achieved through the neighbor-joining (NJ) method with 1000 replicate bootstraps (Saitou and Nei 1987; Felsentein 1985). The evolutionary distances were computed using the Kimura 2-parameter method (Kimura 1980). The rate variation among sites was modeled with a gamma distribution (shape parameter $=5$ ). All ambiguous positions were removed for each sequence pair (pairwise deletion option).

\section{RESULTS AND DISCUSSION}

\section{Taxonomic Treatment of Dorstenia in Java}

Updated key to the Dorstenia of Java

1. A. Acaulescent, leaves shallowly to deeply lobed

B. Caulescent, leaves unlobed

2. A. Stem terete, sap milky yellow, leaf blade oblong, margin entire or dentate, receptacle irregularly lobed to angular in outline, unappendaged .................... D. bahiensis

B. Stem tuberous, sap milky white, leaf blade oblong, obovate, to elliptic, margin crisped, receptacle circular in outline, linear appendages present
Dorstenia bahiensis Klotzsch ex Fisch. and C.A. Mey., Index Seminum (LE) 11: 64 1846; Berg, Fl. Neotropica Monogr. 83: 187-188 2001. Type: Luschnath s.n.; 25 Jun 1837; Brazil: Bahia: Ilhéus (holo: LE; iso: B, BR). -Fig. 1

Dorstenia anthuriifolia S.F. Blake, Contr. U. S. Natl. Herb. 20: 2371919.

Dorstenia cordifolia Mart. Ex Miq., Fl. Bras. 4(1): 165 1853.

Dorstenia longipes Mart. Ex Bureau, Prodr. 17: 262 1873.

Dorstenia martiana Miq., Fl. Bras. 4(1): 1651853.

Herb, caulescent with milky yellow sap; internodes short. Stipules subulate, 5-6 × 2-7 mm, fleshy, brownish to blackish green. Leaves spirally arranged; petiole $4-18 \mathrm{~cm}$ long, brownish to blackish green, slender; leaf blade oblong, $10-27 \times 4.5-13 \mathrm{~cm}$, base cordate or truncate, margin entire to denticulate, apex acuminate; adaxial surface pale green to shiny dark green, glabrous, abaxial surface pale, glabrous; veins prominent on abaxial surface. Inflorescence bisexual, axillary, discoid, green to purplish green; peduncle up to $15 \mathrm{~cm}$ long, slender, curved, glabrous, green to purplish green; receptacle centrally attached, concave, irregularly lobed to angular in outline, $2.5 \mathrm{~cm}$ wide, margin lobed, purple. Staminate flowers numerous; tepals connate; stamens 2; filament white; anthers purple. Pistillate flowers numerous; tepals tubular, membraneous, white; ovary free, ovoid, white; stigma filiform, white. Fruits drupelet, ovoid, up to $1.5 \mathrm{~mm}$ wide, tuberculate, exocarp white.

Distribution. Native to Pernambuco and Bahia, Eastern Brazil (Berg 2001; de Castro 2006).

Habitat. The species grows in moist and shaded places at low elevations (Berg 2001).

Specimen examined. West Java: Cult. in Hort. Bog., leg ign s.n. (BO); in front of Treub Laboratory, BBG, Bogor, 12 August 2019, MR Hariri 45 (FIPIA); Mekarwangi Village, Lembang, Bandung Barat Regency, 12 August 2019, ASD Irsyam 282 (FIPIA).

Vernacular name. Tusuk konde, anthurium konde (Bahasa Indonesia).

Etymology. The epithet refers to the species being native to Bahia (Gledhill 2008).

Status. Cultivated. However, a wild population of $D$. bahiensis was found in Mekarwangi Village, Lembang, and it is presumed to have escaped from cultivation. The wild population grows in a shaded and moist habitat near a home garden. In BBG, the species were also growing outside the collection block. This finding showed that $D$. bahiensis has the potential to become naturalized in Java. The species was previously reported as a naturalized alien species from Kerala, India, in 2008 (Upadhyay et al. 2008). Based on direct observation, the infructescence of $D$. bahiensis is capable of exploding, which catapults the small fruits into the adjacent area. Moreover, the fruit is easily dispersed by water after the explosion.

Dorstenia contrajerva L., Sp. Pl. 121 1753; Overbeck, Jahrb. Wiss. Bot. 66467 1924; Woodson, Ann. Missouri Bot. Gard. 47 177, f. 62 1960; Backer and Bakh. f., Fl. Java 2: 17 1965; Berg, Fl. Neotrop. Monogr. 83: 198 2001; 
Berg, Corner \& Jarrett, Fl. Males. Ser. I, 17(1): 145-146 2006. - Dorstenia quadrangularis Stokes, Bot. Mat. Med., 4, 338 1812. Type: Habitat in nova Hispania, Mexico, Peru, Vera Cruce, insula Vicentii, "Dorstenia" in Plumier, Nov. Pl. Amer., 29, t. 8, 1703 (lecto).

Dorstenia contrajerva L. var. Houstonii L., Sp. Pl. 121 1753. - Dorstenia houstonii (L.) L., Sp. Pl. ed. 2. 176 1762-1763. - Dorstenia quadrangularis Stokes var. Integrifolia Stokes, Bot. Mat. Med., 4, 3391812.

Dorstenia alexiteria L., Syst. Nat., Ed. 10 2: 8891759.

Dorstenia quadrangularis Stokes var. pinnatifida Stokes, Bot. Mat. Med., 4, 3411812.

Dorstenia quadrangularis Stokes var. sinuata Stokes, Bot. Mat. Med., 4, 3391812. 1827.

Dorstenia palmata Willd. ex Schult., Mant. 3: 317

Dorstenia maculata Lem., Ill. Hort. 10: t. 3621863. Dorstenia contrajerva L. var. maculata (Lem.) Bureau in DC., Prodr. 17: 2601873.

Dorstenia contrajerva L. subsp. tenuiloba Blake, Contr. U.S. Natl. Herb. 24: 2, t. 1. 1922 - Dorstenia contrajerva
L. var. tenuiloba (Blake) Standl. and Steyerm., Publ. Field Mus. Nat. Hist., Bot. Ser. 23: 401944.

Herb, acaulescent with milky sap; internodes short. Stipules subulate, 3-6 × 2.5-5 mm, fleshy, green, puberulous. Leaves spirally arranged; petiole $13-23 \mathrm{~cm}$ long, green, slender; leaf blade lobed to partited or cordate to hastate, 7-22 × 7-26.5 cm, base cordate or hastate, apex acuminate; adaxial surface yellowish green to dark green, hirtellous to subhirsute or scabrous, abaxial surface glaucous, puberulous to hispidulous; veins prominent beneath. Inflorescence bisexual, axillary, discoid, green; peduncle 22.5-31.5 cm long, slender, scabrous, green; receptacle eccentrically attached, irregularly lobed to quadrangular in outline, $2.5-3 \mathrm{~cm}$ wide, margin lobed, green. Staminate flowers numerous; tepals connate; stamens 2; filament white; anthers yellow. Pistillate flowers numerous; tepals tubular, membranous, yellowishwhite; ovary free, compressed ovoid, cream; stigmas 2, filiform, white. Fruits drupelet, ovoid, up to $2 \mathrm{~mm}$ wide, tuberculate, exocarp white.

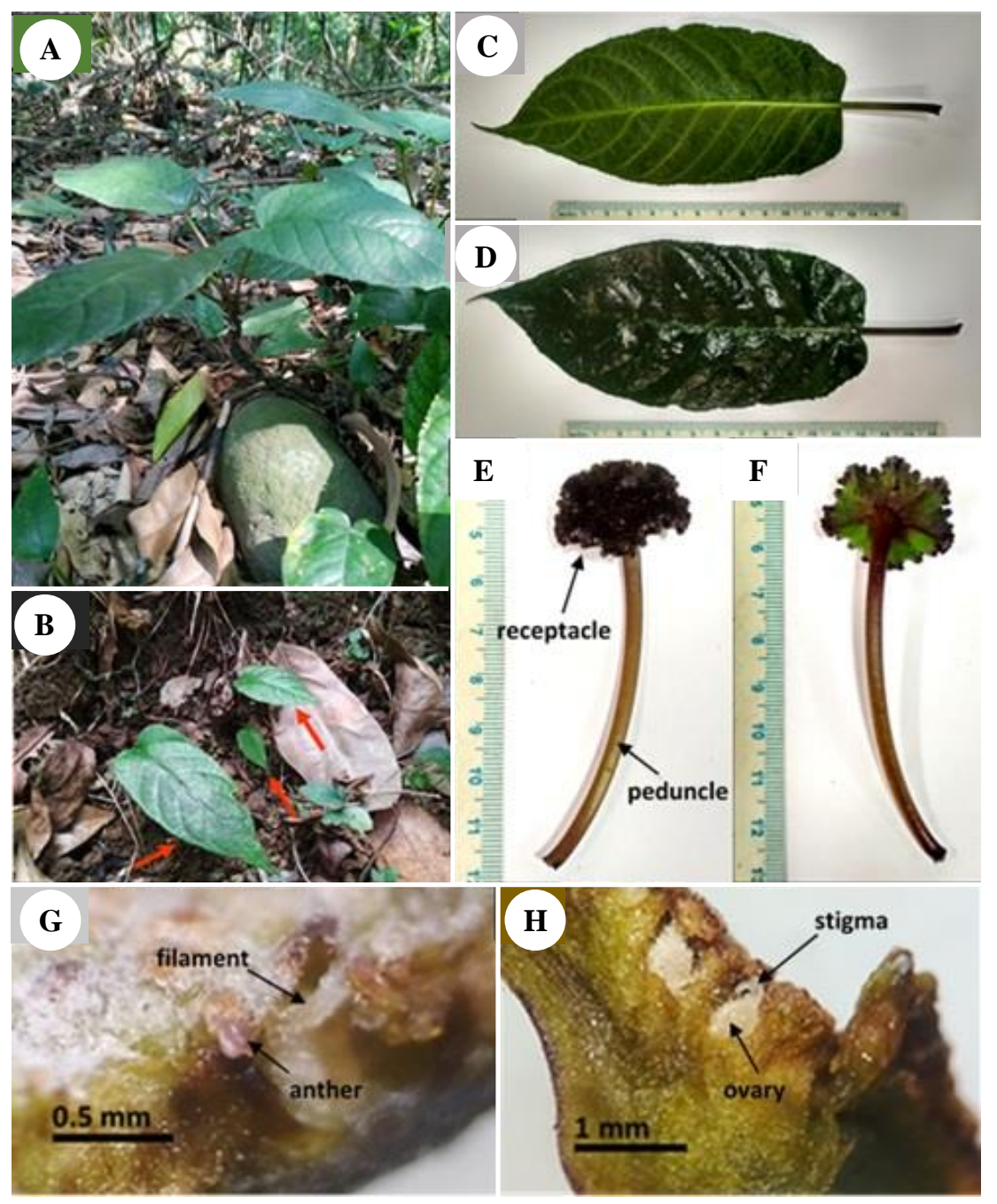

Figure 1. Morphology of Dorstenia bahiensis: A. Living plant. B. A small wild population in Mekarwangi Village, Bandung (arrows). C. Abaxial surface of the leaf. D. Adaxial surface of the leaf. E. Upperside of inflorescence. F. Lower side of inflorescence. G. Male flowers. H. Female flowers. Photo A taken from MR Hariri 45 and photos B-H taken from ASD Irsyam 282. 
Distribution. Mexico to Panama, West Indies, Colombia, northern Venezuela, western Ecuador, northern Amazonian Peru. The species was introduced to Malesia (Java) (Berg 2001; Berg et al. 2006).

Specimen examined. Jakarta: Parapatan, Weltevreden, Batavia, 18 March 1903, C.A. Backer 33665 (BO); Parapatan, Weltevreden, Batavia, 19 June 1903, C.A. Backer 33666 (BO). West Java Cult. in Hort. Bog., Leg ign s.n. (BO); Cult. in Hort. Bog., 12 May 1893, Hallier D573a (BO); Cult. in Hort. Bog., 10 April 1893, Hallier D573b (BO); in front of Treub Laboratory, BBG, Bogor, 12 August 2019, MR Hariri 44 (FIPIA); Schoolweg, 700 m, Bandoeng, Preanger Reg., 22 November 1922, C.A. Wisse 973 (BO).

Vernacular name. Tusuk konde (Bahasa Indonesia).

Etymology. The epithet 'contrajerva' means counter herb in Spanish, because the root of $D$. contrajerva is used as an antidote to snakebite (Cassidy and Le Page 2002).

Status. Naturalized.

Dorstenia foetida (Forssk.) Schweinf., Bull. Herb. Boissier 4 (App. 2): 120 1896; Friis, Nord J Bot 3(5): 536 1983. - Kosaria foetida Forssk., Fl. Aegypt.-Arab. Cxxi 1775. Type: Hadie, Yemen, Forsskål s.n. (Holo C). -Fig. 2 1791.

Cosaria forskahlii J.F. Gmel., Syst. Nat. 2(1): 22, 71

Dorstenia arabica Hemsl., Hooker's Icon. Pl. 26: t. 25031899.

Dorstenia crispa Engl., Monogr. Afrik. Pflanzen-Fam. 1: 271898.

Dorstenia foetida subsp. lancifolia (Rendle) Friis, Nordic J. Bot. 3: 538 1983. - Dorstenia crispa var. lancifolia Rendle, J. Bot. 53: 3021915.

Dorstenia crispa var. pachypoda Chiov., Result. Sci. Miss. Stefanini-Paoli 1. 1916.

Dorstenia foetida var. obovata (A. Rich.) Engl., Monogr. Afrik. Pflanzen-Fam. 1: 27 1898. — Dorstenia obovata A. Rich., Tent. Fl. Abyss. 2: 1851.

Dorstenia phillipsiae Hook. f., Bot. Mag. 125: t. 7676 1899.

Dorstenia radiata Lam., Encycl. 2: 3181786.

Herb, succulent with milky white latex; internodes short. Stipules fleshy, subulate from a broad base, 1-2 mm, very minute, white. Leaves spirally arranged; petiole 17-23 $\mathrm{mm}$ long, green, slender; leaf blade obovate, oblong, to elliptic, 43-60 × 20-25 mm, base cuneate, margin crisped, apex acute to obtuse; adaxial surface dark green, scabridulous, abaxial surface glaucous, sparsely puberulous; veins prominent beneath; leaves foetid when bruised. Inflorescence bisexual, axillary, discoid, green; peduncle 6-20 mm long, slender, green; receptacle green, circular in outline, 9-14 mm wide; appendages 8-10, linear-triangular, 1-6 mm long, green. Staminate flowers numerous; tepals connate; stamens 2; filament white; anthers white. Pistillate flowers numerous; tepals tubular, membranous, greenish-white; ovary free, ovoid, trigonous, cream; stigma simple, unbranched, white. Fruits drupelet, ovoid, trigonous, up to $1 \mathrm{~mm}$ wide, tuberculate, exocarp pale brown.

Distribution. Yemen, Somalia, Ethiopia, Sudan, Kenya, and Tanzania (Friis 1983).

Habitat. Limestone, dry woodland, and deciduous bushland at elevation 100-2100 m alt (Friis 1983).

Specimen examined. Banten: culta, Tangerang Selatan, 3 November 2019, MR Hariri 62 (FIPIA); Jakarta: Culta, Jakarta Utara, 11 August 2019, MR Hariri 43 (FIPIA); East Java: Culta, Surabaya, 3 November 2019, MR Hariri 63 (FIPIA).

Vernacular name. Tusuk konde hias (Bahasa Indonesia).

Etymology. The epithet 'foetida' refers to the foulsmelling of this species (Gledhill 2008).

Status. Cultivated.

\section{Molecular analysis of Dorstenia bahiensis in Java}

Dorstenia bahiensis is commonly and mistakenly identified as D. elata by Javanese horticulturists. Both $D$. bahiensis and D. elata are native to Eastern Brazil. However, their morphological characteristics are different and can be easily distinguished, as listed in Table 1. The morphological characteristics of D. elata used as a comparison to D. bahiensis are taken from dos Santos et al. (2016) because D. elata presence, currently, is not known in Indonesia.

The molecular approach using ITS sequence was carried out to ensure the species delimitation between $D$. bahiensis and D. elata. The reconstructed phylogenetic tree generated through the NJ method and the Kimura 2parameter model with gamma distribution showed that both samples of D. bahiensis are clustered together with $D$. arifolia HQ214101. Those three are in a different cluster than D. elata HQ214087.1, as shown in Figure 3, which clearly states that $D$. bahiensis in Java is a different species from D. elata.

Table 1. Distinguishable morphological characteristics between Dorstenia bahiensis and D. elata

\begin{tabular}{lll}
\hline Distinguishable characteristics & D. bahiensis & D. elata (dos Santos et al. 2016) \\
\hline Shape of stipule & Subulate & Foliaceous \\
Leaf blade & Oblong & Elliptic-obovate \\
Leaf apex & Acuminate & Acute to obtuse-rounded \\
Abaxial surface & Glabrous & Puberulous to pubescent \\
Indument on peduncle & Glabrous & Puberulous to pubescent \\
Appendages on receptacle & Present & Absent \\
Shape of fruit & Ovoid & Globose \\
\hline
\end{tabular}



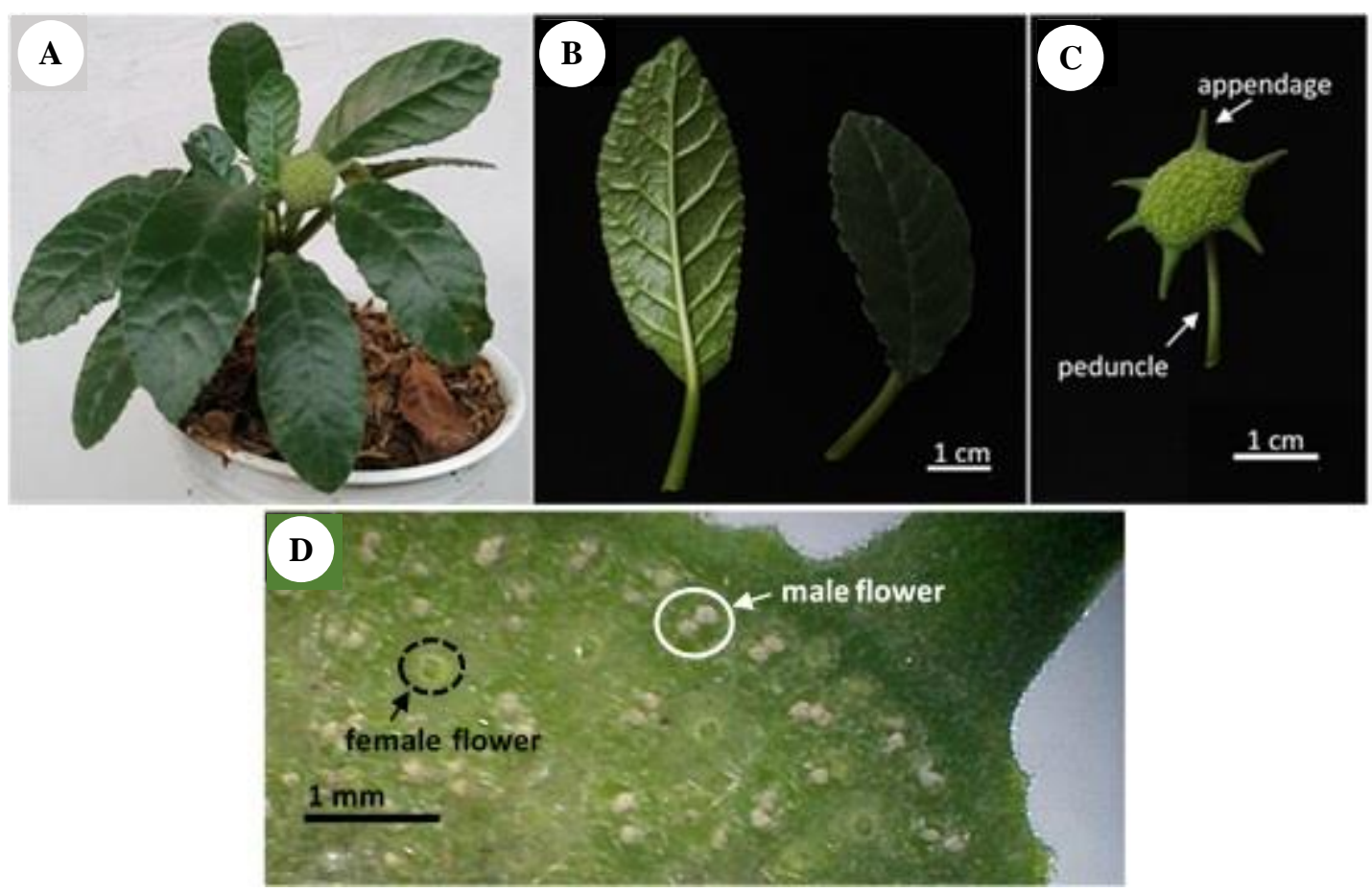

Figure 2. Morphology of Dorstenia foetida: A. Living plant. B. Abaxial surface (left) and adaxial surface (right) of the leaf. C. The whole inflorescence. D. Zoom in of inflorescence shows female and male flowers. All photos taken from MR Hariri 63.

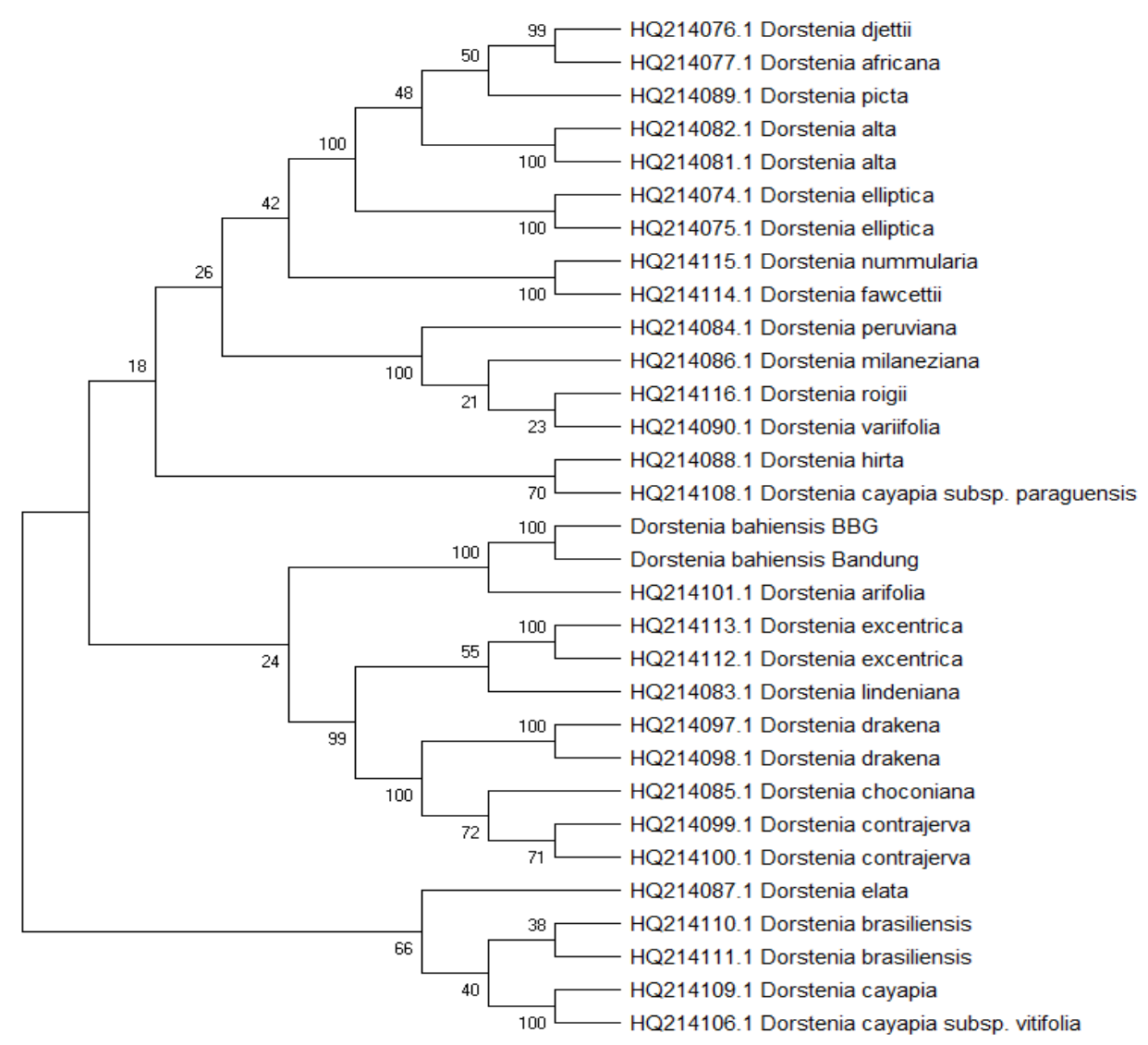

Figure 3. The evolutionary tree of Dorstenia generated from internal transcribed spacer sequence using the neighbor-joining method and Kimura 2-parameter 


\section{ACKNOWLEDGEMENTS}

We thank the Director of Herbarium Bogoriense (BO) and the curator for permitting us to use the specimens. Gratitude is also due to the Director of Bogor Botanic Gardens and the Head of Treub Laboratory, Bogor for their permission and support during the research.

\section{REFERENCES}

Backer CA, Bakhuizen van den Brink RC. 1965. Flora of Java. NVP Noordhoff, Groningen, The Netherlands.

Berg CC. 2001. Moreae, Artocarpeae, and Dorstenia (Moraceae): With Introductions to the Family and Ficus and With Additions and Corrections to Flora Neotropica Monograph 7. New York Botanical Garden Press, New York.

Berg CC, Corner EJH, Jarrett FM. 2006. Moraceae - genera other than Ficus. Fl. Males. - Ser. 1, Spermatophyta 17 (2): 1-702.

Cassidy FG, Le Page RB. 2002. Dictionary of Jamaican English. (2nd ed). The University of The West Indies Press, Jamaica.

Chase MW, Thijs KW, Kamau P, Fay MF. 2013. Dorstenia christenhuszii (Moraceae), a new species from the Taita Hills, Kenya. Phytotaxa. 81 (2):45-48. DOI: 10.11646/phytotaxa.81.2.1.

de Castro RM. 2006. Flora da Bahia - Moraceae [Dissertation]. Universidade Estadual de Feira de Santana, Feira de Santana, Bahia.

Boeni BDO, Singer RB. 2015. Synopsis of Dorstenia (Moraceae) in Rio Grande do Sul, Southern Brazil. Anais da Academia Brasileira de Ciências. 87 (2): 925-942. DOI: 10.1590/0001-3765201520140369.

dos Santos A, de São José PA, Filho MDMV, Neto SR. 2016. Dorstenia (Moraceae) da região da Serra da Mantiqueira, Brasil. Rodriguesia 67 (1):237-250
Felsenstein J. 1985. Confidence limits on phylogenies: An approach using the bootstrap. Evolution. 39:783-791. DOI: 10.2307/2408678.

Friis L. 1983. The acaulescent and succulent species of Dorstenia sect. Kosaria (Moraceae) from NE tropical Africa and Arabia. Nordic J Bot 3 (5): 533-538. DOI: 10.1111/j.1756-1051.1983.tb01463.x.

Gledhill D. 2008. The Names of Plants. 4th ed. Cambridge University Press, Cambridge.

Kimura M. 1980. A simple method for estimating evolutionary rate of base substitutions through comparative studies of nucleotide sequences. J Mol Evol 16: 111-120. DOI: 10.1007/BF01731581.

Kumar S, Stecher G, Li M, Knyaz C, Tamura K. 2018. MEGA X: Molecular Evolutionary Genetics Analysis across computing platforms. Mol Biol Evol 35: 1547-1549. DOI: 10.1093/molbev/msy096.

Misiewicz TM, Zerega NC. 2012. Phylogeny, biogeography and character evolution of Dorstenia (Moraceae). Edinburgh J Bot 69 (3): 413-440. DOI: $10.1017 / \mathrm{S} 096042861200025 \mathrm{X}$.

Rugayah, Retnowati A, Windadri FI, Hidayat A. 2004. Pengumpulan Data Taksonomi. In: Rugayah, Widjaja EA, Praptiwi (eds.). Pedoman Pengumpulan Data Keanekaragaman Flora. Pusat Penelitian BiologiLIPI, Bogor. [Indonesian]

Saitou N, Nei M. 1987. The neighbor-joining method: A new method for reconstructing phylogenetic trees. Mol Biol Evol 4: 406-425. DOI: 10.1093/oxfordjournals.molbev.a040454.

Sun Y, Skinner DZ, Liang GH, Hulbert SH. 1994. Phylogenetic analysis of Sorghum and related taxa using internal transcribed spacers of nuclear ribosomal DNA. Theor Appl Genet 89 (1): 26-32. DOI: 10.1007/BF00226978.

Upadhyay GK, Ansari AA, Dalai AK. 2008. Dorstenia bahiensis Klotzsch Ex Fisch. and C.A. Mey. (Moraceae)-first naturalised record for India. Indian J For 31:479-482.

van Balgooy MMJ. 1987. Collecting. In: de Vogel EF (ed.). Manual of Herbarium Taxonomy Theory and Practice. UNESCO for Southeast Asia, Jakarta. 